\title{
Informeel klantcontact bij de Big 4-organisaties
}

\section{De verschillen tussen accountants en adviseurs nader bekeken}

\section{Yvette Taminiau en Liselore Berghman ${ }^{1}$}

SAMENVATTING Dit artikel beschrijft een exploratieve studie naar het belang dat adviseurs en accountants, werkzaam bij de Big 4-organisaties², toekennen aan informeel klantcontact. De verschillen tussen accountants en adviseurs worden nader onderzocht vanuit diverse wetenschappelijke perspectieven: vanuit relatiemanagement literatuur en vanuit de wetenschappelijke literatuur over institutionele regels van professies. De verschillen tussen accountants en adviseurs bestaan voornamelijk uit de verschillen in informele settings, motieven voor informele klantcontacten en het belang van institutionele regels (zoals de codes of conduct).

\section{RELEVANTIE VOOR DE PRAKTIJK De vergelijking geeft inzicht in de complexiteit en} de uitdagingen van het initiëren en het onderhouden van informeel klantcontact bij zowel accountants als adviseurs werkzaam bij de Big 4-organisaties. De studie laat bovendien zien dat zowel accountants als adviseurs veel belang hechten aan informeel contact met de klant, hun motieven voor het gebruik van informele klantcontacten verschillen echter wel.

\section{Introductie}

Deze exploratieve studie naar informeel klantcontact bij adviseurs $^{3}$ en accountants werkzaam bij Big 4-organisaties beschrijft de verschillen tussen accountants en adviseurs met betrekking tot informeel klantcontact. Informele klantcontacten zijn de contacten tussen de accountant/ adviseur en de klant die in een ongedwongen sfeer ontstaan, bijvoorbeeld tijdens borrels, lunches en diners (Sturdy et al., 2006). Informeel klantcontact faciliteert de kennismaking en de uitwisseling van informatie en gedachten. Daarnaast worden informele contacten voornamelijk gebruikt om werkrelaties te verbeteren en nieuwe klanten te werven (Whittle, 2006).

De centrale onderzoeksvraag is: Wat zijn de belangrijkste verschillen tussen informeel klantcontact bij accountants en bij adviseurs werkzaam bij de Big 4-organisaties?

De deelvragen richten zich ook op de verschillen tussen accountants en adviseurs:
- wat zijn de belangrijkste verschillen in de manier waarop informeel klantcontact wordt vormgegeven (welke activiteiten) tussen de twee beroepsgroepen?

- wat zijn de verschillen in motieven om informeel klantcontact te initiëren en te onderhouden tussen de twee beroepsgroepen?

- wat zijn de verschillen in de impact van institutionele regels op informeel contact en hoe verhouden deze verschillen zich tot de twee verschillende professies, accountancy en advisory?

Wij zullen in paragraaf 2 ingaan op de vraag wat er in de wetenschappelijke literatuur bekend is over informele relaties tussen adviseurs en hun klanten, alsook over de regels rondom professioneel klantcontact. Vervolgens wordt uiteengezet hoe dit onderzoek is uitgevoerd (paragraaf 3) en worden de resultaten gepresenteerd in de resultatensectie (paragraaf 4). In de sectie analyse (paragraaf 5) zullen we dieper in gaan op de vergelijking tussen accountants en adviseurs op basis van de eerder uitgewerkte theoretische thema's. Tot slot zullen we in paragraaf 6 de belangrijkste conclusies, suggesties voor vervolgonderzoek en aanbevelingen presenteren.

\section{Informele klantcontacten: betrokkenheid en afstand}

\subsection{Informele setting}

In de wetenschap is uitgebreid onderzoek gedaan naar de rol van persoonlijke contacten in de zakenwereld. Managementliteratuur, praktijkervaringen en verschillende wetenschappelijke onderzoeken geven aan dat persoonlijke contacten, ofwel informele klantcontacten, een cruciale rol spelen in het bedrijfsleven (Czarniawska en Mazza, 2003; Kubr, 2002, Sturdy et al., 2006). Er is echter nog weinig onderzoek gedaan naar de specifieke rol van persoonlijke contacten in de ontwikkeling van business relaties (Appelbaum en Steed, 2005). Eén van de manieren om een nauwe band te ontwikkelen, is door op zoek te gaan 
naar de ruimte waarin de grenzen tussen organisaties kunnen verdwijnen en waar informeel contact het beste gedijt: de informele setting (Sturdy et al., 2006). Deze setting wordt regelmatig gebruikt om relaties te verstevigen en op een soepele wijze informatie uit te wisselen. Het feit dat deze setting zich onderscheidt van de gebruikelijke zakelijke setting, maakt het mogelijk om persoonlijke onderwerpen aan te kaarten en het gesprek op een minder strikte wijze te laten verlopen (Taminiau et al. , 2009).

\subsection{De klantrelatie: afstandelijkheid, betrokkenheid en spanningen}

Het traditionele beeld van de adviseur is dat van een buitenstander die op een rationele, zakelijke wijze advies uitbrengt, zonder werkelijke betrokkenheid (Werr en Styhre, 2002). Afstand is belangrijk om het werk goed te kunnen doen. Deze benadering wordt beschreven als de functionele benadering (Werr en Styhre, 2002). Als reactie op dit ietwat naïeve beeld is er inmiddels een meer kritische benadering ontstaan. Deze benadering benadrukt dat de adviseur voortdurend op zoek is naar nieuwe opdrachten en dientengevolge de klant via retorische handigheden en overredingskracht verleidt tot steeds weer nieuwe verbintenissen (Alvesson en Johansson, 2002; Clark, 1995; Berglund en Werr, 2000; Clark en Salaman, 1998; Werr en Styhre, 2002). Volgens deze visie is niet de afstand tussen adviseur en klant het voornaamste belang, maar juist de nabijheid en betrokkenheid tussen hen, waarbij de macht bij de adviseur ligt (Czarniawska en Mazza, 2003, Kitay en Wright, 2004). Recentelijk is aan deze visie de nuancering toegevoegd dat ook de klant wel degelijk veel te zeggen heeft binnen de relatie, vooral in een context van verhevigde competitie. Daarnaast wordt er in de laatste jaren meer nadruk gelegd op het gegeven dat de manier waarop de relatie wordt vormgegeven sterk afhankelijk is van de context, en dat deze dynamisch van karakter is (Appelbaum en Steed 2005; Kubr, 2002; Sturdy et al., 2009).

Uit onderzoek van Glückler en Ambrüster (2003) blijkt dat de meeste adviesopdrachten terechtkomen bij consultants waarmee men reeds een goede en persoonlijk ervaring heeft gehad. Czerniawska (2007) stelt het zo: zonder een goede relatie kan de adviseur zijn werk niet goed doen en zonder goed werk krijgt de adviseur geen goede relatie. Daarom is het voor de adviseur cruciaal om de wensen van de klant goed te kunnen 'lezen' zodat hij/zij weet aan welke behoeften er zou moeten worden of kan worden voldaan. Maister (2005) stelt dat de adviseur erop uit moet zijn de relatie te ontwikkelen tot een emotioneel duet. Hij vergelijkt de consultant-klant-relatie zelfs met een romance. Net als in 'echte leven' worden eigenschappen als betrouwbaar, authentiek, open, attent, empathisch en begripvol als waardevolle eigenschappen gezien. Binnen de relatie adviseur- klant wordt echter verwacht dat de adviseur zich meer schikt naar de wensen en behoeften van de klant dan andersom het geval is (Czerniawska, 2007). Kubr (2002) stelt eveneens in zijn gids voor management adviseur professionals: het is noodzakelijk om een begripvolle relatie, een solide samenwerking en vertrouwen te creëren in relatie tot de klant. Zonder dit alles: 'There is no effective consulting' (Kubr, 2002, p. 66). Deze mening wordt gedeeld door Appelbaum en Steed (2005); zij stellen daarbij dat een sterke relatie tussen klant en adviseur hét concurrentiëel onderscheidend criterium binnen professionele serviceorganisaties is. Uit ditzelfde onderzoek blijkt echter dat de scheidslijn tussen het succes en het falen van de relatie tussen klant en adviseur zeer smal kan zijn (Appelbaum en Steed, 2005). In eerder onderzoek is daarbij de nadruk vooral op de positieve kenmerken van persoonlijke relaties gelegd, terwijl ook negatieve en/of paradoxale effecten invloed kunnen hebben op de ontwikkeling van business relaties (Whittle, 2006).

Whittle (2006) laat zien dat de activiteiten die een adviseur uitvoert om zijn/haar werk goed te doen veel paradoxale elementen inhouden. De drie meest relevante daarvan worden kort benoemd:

1) de adviseur moet oplossingen presenteren, maar moet zich tegelijkertijd onmisbaar maken door nieuwe problemen te signaleren;

2) de adviseur moet gelijktijdig optreden als afstandelijke wetenschapper (kritisch) en als betrokken cocreator (vriend);

3) de adviseur moet het advies presenteren als standaardoplossing (commodity), maar ook als maatwerk.

Deze verschillende rollen kunnen worden gezien als uitersten op een continuüm. Aan het ene uiteinde staat de adviseur als kritische wetenschapper die gebruik maakt van een beproefd model die voor de oplossing zorgt (zie ook Heusinkveld en Benders, 2005). Aan de andere kant staat een zeer betrokken adviseur (bijna een vriend) die probeert zichzelf onmisbaar te maken door maatwerk te leveren. De werkelijke rol die een adviseur aanneemt bevindt zich echter vaak in het midden en is daarnaast ook sterk afhankelijk van de klant en de fase waarin de relatie zich bevindt. Vooral zakenmensen in de top van het bedrijfsleven zijn zeer vaardig in het switchen tussen deze verschillende rollen en in het overstappen van een zakelijke omgeving naar een informele ruimte (Kanter, 1977). Het al dan niet (mogen) deelnemen aan deze informele ruimte wordt bepaald door hiërarchische verhoudingen en is vaak een weerspiegeling van de formele organisatiestructuur (Sturdy et al., 2006). Zo onderhoudt een adviseurpartner informeel contact met een CEO of directeur, terwijl de accountant-partner dat doet met de CFO van de klantorganisaties in de bewust gekozen informele settings. 


\subsection{Institutionele inbedding: de regels}

Klantbetrokkenheid is ook belangrijk voor accountants, maar in vergelijking met adviseurs hebben accountants vaker te maken met regels die van invloed zijn op de relatie met de klant. Een belangrijke reden voor bedrijven en organisaties om accountants in te schakelen is de wettelijke verplichting om hun jaarrekening te laten controleren en een accountantsverklaring te ontvangen. Vanwege deze specifieke taak, waarin het bewaren van hun onafhankelijkheid een eerste vereiste is, ligt het in de lijn der verwachtingen dat accountants anders met klantcontacten zullen omgaan dan adviseurs. Informele contacten met klanten zouden immers de onafhankelijke expertrol kunnen aantasten (Gendron et al., 2006).

$\mathrm{Na}$ de invoering van de Sarbanes-Oxley Act (SOX) in 2002, naar aanleiding van de ondergang van Enron en Arthur Andersen, zijn de reeds bestaande regels flink aangescherpt. Deze formele regels hebben een onmiddellijk effect op de wijze waarop accountants hun werk kunnen doen zonder 'conflicts of interests' met andere activiteiten binnen de organisatie. De beroepsorganisatie van accountants (NIVRA) heeft strenge regels opgesteld voor het bewaken van onafhankelijkheid, objectiviteit en integriteit van de accountants 4 . Los nog van externe regelgeving worden objectiviteit en onafhankelijkheid door de beroepsgroep van accountants zelf ook als essentiële onderdelen van de professie gezien (Hayes et al., 2005; Vergoossen en Wallage, 2004). Het belang dat een accountant objectief en onbevooroordeeld opereert is dus sterk verankerd in de accountantsberoep (Bollom, 1988; Wallage, 2008). Onafhankelijkheid betekent echter niet dat accountants zich niet betrokken zouden mogen voelen bij hun klanten. Gendron et al., (2006) tonen aan dat grote betrokkenheid bij de klant de onafhankelijkheidspositie niet in de weg hoeft te zitten. Betrokkenheid en onafhankelijkheid kunnen elkaar juist versterken.

Bij de adviseurs van de Big 4 speelt onafhankelijkheid in toenemende mate een rol doordat er externe onafhankelijkheidsregels op organisatieniveau gelden die van invloed zijn op alle activiteiten. Adviseurs hebben eigen richtlijnen over objectiviteit en onafhankelijkheid zoals geformuleerd door de Raad van Organisatie-Adviesbureaus (ROA). Deze richtlijnen hebben echter een vrijblijvend karakter (Strikwerda, 2000). Daarnaast hebben de Big 4-organisaties ook gedragscodes (codes of conduct) opgesteld voor hun partners en werknemers, die met name een grote impact blijken te hebben op de adviseurs die werkzaam zijn bij de Big 4-werknemers. Gedragscodes zijn schriftelijke verklaringen die de grondbeginselen vormen van het beleid en zich voornamelijk richten op onafhankelijkheid en loyaliteit (Burchell et al., 1980; Diller, 1999). Deze codes gaan vooral over het wel of niet mogen aannemen/aanbieden van geschenken en over de types relaties waarmee men geen zakelijke verhouding mag aangaan (zoals familie). De regels gelden zowel voor accountants als voor adviseurs. Verwacht mag worden dat deze gedragscodes van invloed zijn op de manier waarop accountants en adviseurs hun klantrelaties vormgeven aangezien ze beperkingen opleggen maar tegelijkertijd ook houvast kunnen bieden in geval van twijfel.

\section{Het materiaal en methode van onderzoek}

Omdat het wetenschappelijk onderzoek naar informele klantcontacten nog in de kinderschoenen staat, hebben we gekozen voor een kwalitatief onderzoeksontwerp (Sturdy et al., 2009). Deze methode biedt de mogelijkheid om nauwkeurige gegevens te verzamelen over hoe accountants en adviseurs vormgeven aan hun informele klantcontacten (Maxwell, 1998). Informeel klantcontact is een belangrijk onderdeel van het werk van de adviseur en de accountant. Informeel klantcontact behelst echter activiteiten die moeilijk om te zetten zijn in causale verbanden en daardoor ook lastig te verwerken in een model. Kwalitatief onderzoek op dit gebied kan fungeren als een platform voor verdere theorieontwikkeling (Bacharach, 1989). Tevens kunnen kwalitatieve data ons helpen om te begrijpen hoe adviseurs en accountants betekenis geven aan informeel klantcontact (Maxwell, 1998). We hebben vooral een inductieve benadering toegepast en hebben Strauss'(1987) stelling gevolgd dat analytische inductie door middel van coding en analyse leidt tot een beter beeld van de werkelijkheid.

We zijn begonnen met een literatuurstudie, waaruit wij een aantal centrale thema's hebben gedistilleerd die uiteindelijk zijn omgezet in interviewvragen. De literatuur over adviseurs' klantcontacten kan worden gegroepeerd rondom de volgende thema's: de adviseur-klantrelatie, rituelen in consultancy, transitieruimtes in tijd en plaats, hiërarchie, culturele studies, professies en instititionele regels. Deze thema's vormden voor ons niet alleen een theoretische achtergrond, maar leverden ook de input voor de interviewvragen.

Ons onderzoek, dat deel uitmaakt van een grotere internationale studie in elf Westerse landen, betreft de situatie in Nederland. Het is gebaseerd op 35 semigestructureerde interviews (zeventien accountants en achttien adviseurs) die plaatsvonden in de eerste helft van 2009. De interviews vonden plaats op de kantoren van de respondenten en duurden gemiddeld zestig minuten.

De respondenten waren werkzaam op verschillende hiërarchische niveaus binnen hun organisatie, maar vooral op het hogere niveau (partners en seniorniveau). De reden daarvoor ligt voornamelijk in het feit dat men op deze 
niveaus het meest actief is in het onderhouden van informele klantcontacten. Er zijn dertien interviews afgenomen op het hoogste niveau (partner, associate partner, director); twaalf op senior-manager niveau, vier op manager-niveau; vier op uitvoerende niveaus en twee op junior-niveau. De contacten zijn vooral gelegd via het bestaande netwerk van de onderzoekers en via de respondenten die reeds hadden meegewerkt aan het onderzoek.

Het onderzoek is uiteindelijk in twee delen uitgevoerd: een studie met vijftien respondenten en een studie met twintig respondenten. Bij deze laatstgenoemde studie zijn alle respondenten werkzaam bij één van de Big 4-organisaties. De andere vijftien respondenten zijn werkzaam bij één van de andere drie van de Big 4-organisaties.

De sectoren waarin de responderende accountants en adviseurs werkzaam zijn variëren van financiële dienstverlening, de publieke sector, assurance, vastgoed tot forensische accountancy. Binnen de profit sector varieert het type bedrijf waaraan advies werd gegeven van beursgenoteerd tot middengrote onderneming.

De interviews waren semigestructureerd. We hebben gebruik gemaakt van een standaardvragenlijst om zeker te weten dat alle thema's in elk interview werden behandeld. Tegelijkertijd is er voldoende ruimte gelaten om door te vragen, om de vraag in andere woorden te formuleren, of om de volgorde van de vragen aan te passen. De interviews handelden over de inhoud van het informeel contact, de locaties, de motieven, de timing, de betrokken hiërarchische niveaus en of er trainingen bestaan over informeel klantcontact. Tot slot vroegen we naar de kritische succesfactoren en de 'never do's' van informeel klantcontact. Bij de eerder genoemde studie van twintig respondenten is er nog extra gevraagd naar het belang van formele regels over onafhankelijkheid en de 'codes of conduct' met betrekking tot informeel klantcontact.

Alle interviews zijn letterlijk getranscribeerd en, na op goedkeuring door de respondenten, geanalyseerd volgens de interpretatieve benadering. De data zijn georganiseerd om patronen te herkennen (Berg, 2001). Uiteindelijk hebben we de interviews onderverdeeld in fragmenten en ze dienovereenkomstig gelabeld. Deze labels hebben we vervolgens weer gerangschikt tot een aantal kernlabels. Aan de hand van deze kernlabels is de gehele dataset geanalyseerd. Voor de analyse van het materiaal hebben we vooral gelet op frequentie (hoe vaak een persoon een specifiek onderwerp herhaalde) en op de schaal van de antwoorden (hoeveel personen zeggen hetzelfde). Wij hebben onze bevindingen geillustreerd met representatieve citaten van de respondenten. Onze resultaten vertoonden grote overeenstemming in argumentatie en woordkeuze.

\section{Resultaten}

\subsection{Voorbeelden van informeel klantcontact}

Informele klantcontacten blijken vooral plaats te vinden binnen de hogere niveaus van de organisaties. Het zijn vooral de senior managers, directors en partners die veelvuldig informele contacten onderhouden met hun klant op senior level ('level meets level', dat wil zeggen vaak CEO of CFO). Wel wordt er ook steeds meer aandacht besteed aan informeel klantcontact op lager niveau.

De informele activiteiten variëren van gezamenlijk eten en drinken (lunchen/dineren, closing diners, charity diners, gala's, borrels), naar sportevenementen gaan (voetbal), culturele evenementen bezoeken (concertgebouw, theater, film en tentoonstelling) tot gezamenlijk sporten (golfen, zeilen, tennissen en squashen). Maar ook een praatje in de parkeergarage, bij de koffieautomaat, en een e-mail of telefoontje worden als informeel contact gezien. De topical events (seminars, conferenties en round tables) worden eveneens gezien als een manier om informeel contact te leggen, vooral met nieuwe klanten. Accountants en adviseurs noemen wat dit betreft dezelfde activiteiten en locaties. Adviseurs geven echter meer voorbeelden dan accountants, terwijl accountants meer dan adviseurs gebruik maken van inhoudelijke bijeenkomsten (conferenties, seminars en round tables). Zowel de accountants als de adviseurs stellen dat sommige klanten overladen worden door uitnodigingen van verschillende partijen, en dat het daarom belangrijk is dat de adviseur/accountant de wensen van de klant goed begrijpt.

\subsection{De vergelijking}

Tabel 1 laat zien dat er in eerste instantie geen grote verschillen vallen te ontdekken tussen accountants en adviseurs wat betreft de gebruikte locaties. Informele klantcontacten vinden op allerlei locaties plaats waarbij de inzet zit in het krijgen van een persoonlijke band. De achttien adviseurs noemen iets vaker verschillende voorbeelden (90) dan de zeventien accountants (67). De antwoorden zijn gegeven op de vraag: kunt u enkele informele klantcontacten opsommen (zoals borrel, lunch, sportactiviteit, small talk bij de koffieautomaat)?

\subsection{Motieven}

Informele klantrelaties blijken zich het beste te ontwikkelen wanneer er zorgvuldig rekening wordt gehouden met de wensen en behoeftes van de klant voor wat betreft de locatie, het tijdstip en het onderwerp van gesprek. Binnen de beperkingen die worden opgelegd door de sector (in de publieke sector is het ontwikkelen van informele contacten bijvoorbeeld moeilijker) en het hiërarchisch niveau waarin men opereert, zijn er allerlei mogelijkheden om een sterke band en een diepgaande relatie met een 
Tabel 1 Verschillende vormen van informele activiteiten van accountants en adviseurs

\begin{tabular}{|l|c|c|}
\hline Aard van de informele klanteontacten & Accountants (17) & Adviseurs (18) \\
\hline $\begin{array}{l}\text { Praatje in de wandelgangen/ koffieapparaat/parkeergarage/telefoontje plegen, sms'en, e-mailen/online } \\
\text { netwerken/Linked-in/ Facebook }\end{array}$ & 11 & 15 \\
\hline Diners en 'closing dinners' & 12 & 13 \\
\hline Lunch & 10 & 12 \\
\hline Borrel/drankje/ aperitief & 6 & 15 \\
\hline Golf of andere gezamenlijke sporten (tennissen/squash/zeilen/hardlopen) & 6 & 10 \\
\hline Sportwedstrijd bezoeken (voetbal) & 5 & 7 \\
\hline Topical events/ seminars/ conferenties & 9 & 2 \\
\hline Diverse gesponsorde evenementen & 2 & 8 \\
\hline Beeldende kunst: museum/tentoonstelling & 2 & 3 \\
\hline Concert/theater/cabaret/gala & 3 & 2 \\
\hline Samen reizen & 0 & 3 \\
\hline Kookcursus & 1 & 0 \\
\hline
\end{tabular}

klant te ontwikkelen. Dit proces van aanpassen en elkaar steeds beter leren kennen is tijdrovend, maar ook afhankelijk van ervaring. Uiteindelijk probeert zowel de adviseur als de accountant de kans op de zogenaamde klik- en gunfactor te vergroten, hetgeen uiteindelijk zou moeten leiden tot een langdurige vertrouwensband.

\section{De accountants}

Accountants stellen dat zij door informele klantrelaties in staat zijn om de klanten beter te adviseren en hun rol als expert beter uit te oefenen. Zij stellen zelfs dat zij zonder informeel contact hun werk niet goed kunnen doen. De onderstaande invulling van informeel klantcontact door een accountant laat zien dat informeel klantcontact niet perse hoeft plaats te vinden in een informele setting: Want ik denk dat wij heel erg veel informeel contact hebben als accountants. En waarom? Omdat wij eigenlijk een onbeperkte toegang hebben tot het bedrijf zelf, sterker nog, dat we daar soms gewoon weken achter elkaar zitten. En je klant, die kom je tegen bij de koffieautomaat, die kom je tegen op de gang en kom je tegen in de parkeergarage. Dus het informele contact is dan denk ik nog veel belangrijker en je hebt dus ook veel meer informeel contact dan dat je zou hebben als je adviseur bent. Want dan moet je bellen als je een afspraak wilt maken, anders kom je het gebouw niet eens in. Ik heb van mijn klanten gewoon een pasje en ik loop zo naar binnen. Dus dat is toch anders. (Partner, accountancy).

Volgens deze visie op informeel klantcontact is niet de setting het belangrijkste, maar de informele toegang en de frequentie waarmee de accountant de klant treft. Met andere woorden, de accountant heeft niet zozeer meer informeel contact dan de adviseur in termen van de informele activiteiten die hij onderneemt, maar wel in termen van de kwaliteit van de vertrouwensband en de frequentie van de contacten.
Als het goed is, dan kan een langdurige relatie enkel succesvol zijn als je elkaar begrijpt en als je goed met elkaar kunt samenwerken. Je moet elkaar kunnen vertrouwen, dat is niet helemaal het goede woord, want wij controleren ze, maar je moet elkaars integriteit kunnen vertrouwen. Dus dat betekent dat je echt wel moet werken aan een goede relatie. En hoe beter je relatie is, hoe beter en effectiever en ook efficiënter je werk verloopt. Er worden dan dingen gewoon aan je verteld en dan hoef je niet op zoek om die informatie te vinden. Dus het opbouwen van een goede relatie is cruciaal om goed je werk te kunnen doen. Dus ja, waarom doe je het nou, omdat je anders gewoon je werk niet goed kunt doen, dat is eigenlijk wel het makkelijkste antwoord. (Partner, accountancy).

Eén van de voordelen van informeel klantcontact is dat de accountant meer ruimte krijgt om een project soepel te laten verlopen. Zelfs vertraging of fouten kunnen de accountant worden vergeven.

En het is ook zo belangrijk, ook voor bestaande klanten, dat het contact goed blijft. Want waar gewerkt wordt, worden fouten gemaakt en als er iets gebeurt dan is dat op het moment dat je geen goed contact hebt en alleen zakelijk contact. Dan is dat over of je wordt erop afgerekend. En op het moment dat je goed contact hebt, ook informeel contact, dan wordt dat je vergeven. En zo gaat dat gewoon en daarom is het zo belangrijk. (Partner, accountancy). Los van de praktische zaken kan informeel klantcontact ook tot diepgaande gesprekken leiden. Als een relatie goed van de grond komt, wordt de schaal van onderwerpen die kunnen worden besproken verbreed:

Je moet het meer zien in de gespreksonderwerpen, dat is anders. En dan zie je dat naarmate het informele contact groeit, dat anders is. Kijk, in het begin gaat het toch vaak over zakelijke dingen, of over probleempjes, en dat moet besproken worden. En op een gegeven moment gaat het toch een hele andere kant op, dan gaat het meer over de strategie van de onderneming of over een probleem dat ze 
zelf tegenkomen. Het wordt dan meer opengelegd. Dus het is een ander gesprek, hoe moet je dat zeggen, meer kwetsbaar opstellen. (Partner, accountancy).

Het is natuurlijk ook mogelijk dat de relatie tussen de accountant en de klant niet soepel verloopt. In dat geval is het altijd mogelijk om te proberen de klant door te schuiven naar een collega-partner.

Ik kan me nog een klant herinneren: ik vond het een hoogst vervelend persoon en een collega van mij die vindt hem ook een hoogst vervelend persoon maar hij kan ermee omgaan. Die laat dat allemaal over zich heen komen en blijft vriendelijk glimlachen en heeft daarmee heel veel vertrouwen bij de klant gekregen en daarmee mooie opdrachten binnengehaald. Ik loop me te ergeren en ik ga tegensputteren, kritiek geven en dan vindt die klant mij niet aardig. $\mathrm{Ja}$, nou ja, als dat dus niet past; dat is het mooie van als je 6000 man in dienst hebt, er loopt altijd wel iemand rond die daar wel bij past. En ja, dan moet je die naar voren schuiven. Dat is een beetje het spel dat je met elkaar moet spelen. (Partner, accountancy).

Aandacht geven aan de klant moet worden gezien als langetermijninvestering. Het is belangrijk om in contact te blijven met een potentiële klant, zelf na een afwijzing.

Kijk je weet ook nooit, toevallig zit ik maandag bij een grote prospect en daar heb ik in het verleden ook heel veel energie in gestoken, gratis loonscan en weet ik het allemaal. En het werd niks. Totdat ik een paar maanden geleden eens een belletje kreeg van, ik ben er nu toch wel eens aan toe om een andere accountant in te huren en dan kan het zomaar ineens. (Partner, accountancy).

De accountant ziet vooral instrumentele en functionele voordelen in een goede relatie. Hoewel hij of zij zich wel degelijk bewust is van het belang van informeel klantcontact, blijft het een professie die erg inhoudelijk gedreven is, waardoor de soft skills en relatiebouw pas in een laat stadium van de carrière aanbod komen.

Bij ons worden mensen pas gestimuleerd om meer te doen aan informeel contacten als ze al 6-7-8 jaar bij ons werken en manager gaan worden. Daarvoor moesten ze alleen checken, adviseren en inhoudelijk bezig zijn. En dat is niet goed. Want je moet eigenlijk altijd oog hebben voor informele contacten en relatiebouw. En naarmate je verder bent in je ontwikkeling wordt het plotseling verwacht van je en is het je nooit geleerd. (Partner, accountancy).

\section{De adviseurs}

De adviseur verwoordt het anders dan de accountant. Bij de adviseur draait informeel contact vooral om het plezier van een goede, vertrouwelijke werkrelatie.

[...] en dat is ook het leukste, dat je gewoon iemand persoonlijk goed ligt en dat je iemand even kunt opbellen, van hoe gaat het en dan heb je nog niet eens in eerste instantie het idee om meteen daar een klus weg te halen. Als je ooit wat voor elkaar doet, dan is het ook alleen leuk als ik weet dat het voor beiden een succes wordt. Maar dat is natuurlijk het leukste, dat je eigenlijk bijna gewoon vrienden bent. (Manager, advisory).
Toch blijft het uiteindelijke doel van goed contact voor de adviseur het bereiken van de trusted advisor positie: diegene die gebeld wordt om de problemen te bespreken waar de klant van wakker ligt. In dat kader moet goed worden gewaakt dat de adviseur of accountant niet te opdringerig is, aangezien dat averechts blijkt te werken.

Waar ik naar streef, is om trusted advisor te worden, misschien zelfs wel trusted partner te worden voor mijn klanten. En daar moet je veel tijd en energie in stoppen. En hoe meer tijd en energie je daarin stopt... dat kun je niet voor al je klanten doen. Dus dan moet je ook nog keuzes maken, voor wie je dat doet. Maar hoe meer tijd en energie je daarin stopt des te groter het rendement is. Dus kun je het te veel doen, nee je kunt het niet teveel doen, denk $i k$, maar het is natuurlijk ook een beetje hoe de klant daarop reageert. Ik bedoel je kunt toch moeilijk elke avond bij hem op de stoep staan maar ik denk, ik zou het graag meer willen doen dan dat ik het doe, laat ik het zo zeggen. (Partner, advisory).

Een informele klantrelatie werkt het gemakkelijkst op het moment dat er een persoonlijke band ontstaat tussen de adviseur en de klant. De adviseur zet daarbij meer in op intimiteit, zoals verwoordt door een adviseur die van huis uit accountant is en inmiddels een grote sales afdeling aanstuurt.

Ik wil wel altijd graag zijn persoonlijke passies weten, wat hij echt leuk vindt. Ik laat altijd eerst nadrukkelijk wat van mezelf zien, dat ik zeven kinderen heb en drie vrouwen [lacht] dat ik van hardlopen houd en hardloop. Dus je moet eerst jezelf persoonlijk laten zien voordat je dat de ander kan vragen. Als je gemeenschappelijke passies/interesses hebt, is dat hartstikke leuk. Dat is een basis voor een relatie. (Partner, advisory).

\section{De vergelijking}

Motieven die vaak worden genoemd door de respondenten zijn, onder andere: een vertrouwensband opbouwen, beter informatie uitwisselen, en kansen voor toekomstige opdrachten signaleren (zie tabel 2)5. Het ontwikkelen van een hechte band kan er toe leiden dat de klant de opdracht gunt aan de accountant of adviseur. Het meest interessante verschil tussen de adviseurs en de accountants is wat dat betreft dat de adviseurs vooral gedreven worden door het veiligstellen van vervolgopdrachten, terwijl voor de accountants het inhoudelijke aspect van het grootste belang is: betere informatie.

Zowel kennis en expertise als het goed kunnen omgaan met mensen worden gezien als voorwaarden om het werk goed te kunnen doen, zowel bij accountancy als bij advisory.

Ik denk dat je beiden nodig hebt. Kijk, iemand die alleen maar mooie verhalen kan vertellen die gaat het uiteindelijk niet redden, iemand die het alleen maar van inhoud moet hebben gaat het ook niet redden. (Partner, advisory). 
Tabel 2 Overzicht van de belangrijkste motieven om informeel contact aan te gaan met klanten

\begin{tabular}{|l|c|c|}
\hline Motieven voor het onderhouden van informele klantcontacten & Accountants (17) & Adviseurs (18) \\
\hline Vervolgopdrachten, naamsbekendheid vergroten, andere zakelijke motieven & 10 & 15 \\
\hline Relatie bestendigen, klantenbinding/klanttevredenheid & 10 & 12 \\
\hline Betere informatie, informatie delen, op de hoogte blijven & 9 & 6 \\
\hline Werkplezier & 2 & 7 \\
\hline Vertrouwensband opbouwen & 2 & 4 \\
\hline
\end{tabular}

\subsection{De institutionele inbedding: de regels}

Tot zover hebben we de motieven van zowel de accountants als de adviseurs beschreven vanuit hun persoonlijke visies en ervaringen. Het is vervolgens interessant om te bekijken hoe informeel klantcontact zich verhoudt ten opzichte van de twee verschillende beroepsgroepen (professies) en ten opzichte van de interne regels (codes of conduct).

\section{De accountants}

De accountants hebben strenge institutionele regels die ervoor moeten waken dat de onafhankelijkheid, objectiviteit en integriteit van de accountants worden gewaarborgd. Door deze strenge regels zijn accountants wellicht eerder geneigd om een relatie zakelijk te houden, dan om die al te persoonlijk te maken. Hoe gaan accountants daarmee om? Hieronder de meest illustratieve uitspraak over de impact van formele regels op informeel klantcontact en het belang van het onafhankelijkheidsprincipe voor accountants:

Die regels zijn er zeker. Zeker in mijn vak als accountant zijn integriteit en onafhankelijkheid van belang, dus je moet jezelf niet in een positie brengen die klanten later tegen je kunnen gebruiken. Als een klant dat zou willen. Als je daar maar aan vasthoudt komt het wel goed denk ik. De regels die we hebben zijn helder en daar leven we ook naar. (Partner, accountancy).

De accountant behoort de nodige afstand te bewaren.

Dat het te intiem wordt, dat is echt gewoon kansloos. Dat moet je niet hebben. Echt afstand houden. Tegenwoordig is het heel erg in, zowel bij mannen als vrouwen, dat je elkaar op de wangen zoent als je iemand iets beter leert kennen. Dat is me een keer overkomen bij een vrouwelijke cliënt, maar dat doet ze nooit meer. Ik zeg, ik ben je accountant en het is prima dat we elkaar hartelijk begroeten, maar er wordt niet op de wang gezoend. Dat zijn van die dingen die je, ja...in ons werk altijd zakelijk probeert te houden, ondanks het feit dat het informeel is. Zodra het je vrienden worden, moet je als de sodemieter wegwezen en iemand anders op die klant zetten. (Partner, accountancy).

\section{De adviseurs}

De adviseurs gebruiken de regels (zoals de codes of conduct die gelden binnen de verschillende Big 4-organisaties) op pragmatisch wijze. Ze kennen deze regels in het algemeen niet uit hun hoofd, maar zouden ze wel kunnen 'terug- vinden'. Desnoods zouden ze overleggen met afdelingscollega's over of een informele activiteit binnen de normen van het bedrijf past.

Ja, die regels zijn wel beschreven, soort code of conduct, hoe je daarmee om moet gaan. Maar ik kan ze niet zo opnoemen. Voor mij zijn ze wel logisch. Als ik nou een heel wild idee zou hebben dan zou ik het nooit in mijn eentje uitvoeren maar altijd even checken of we dit kunnen doen. Geen moeite mee. (Adviseur, advisory).

Adviseurs ervaren de codes als een bevestiging van professioneel gedrag. Uit de rol vallen wordt ervaren als onprofessioneel gedrag.

(...) het zijn weliswaar informele contacten, maar je blijft altijd vrij formeel, professioneel praten en je probeert wel ontspannen en relaxt te zijn. Zo laat je een beetje je andere kant zien. Maar er blijft altijd een waakvlammetje aan en je blijft altijd alert: let op ik ben hier adviseur en ik mag niet uit mijn rol vallen, ik mag geen rare dingen zeggen. (Manager, advisory).

Adviseurs verwijzen vaak naar een eigen verantwoordelijkheidsgevoel, gezond verstand en goed fatsoen.

Meer gezond verstand. Eigen verantwoordelijkheidsgevoel. Als je alleen maar aan het lunchen bent of declareren wordt daar wel wat van gezegd. (Partner, advisory).

De adviseurs ervaren ook dat er voldoende ruimte is binnen de regels:

We zijn wel aan regels gebonden, maar binnen die regels kan heel veel. Het hoeft niet allemaal heel duur te zijn. Je kunt wel honderden dingen verzinnen. En iedereen vindt het leuk om op een zeilboot te zitten, of om eens een hapje te gaan eten. Dat moet allemaal kunnen binnen de grenzen van de regels. (Partner, advisory)

In de codes of conduct staat ook beschreven hoe er dient te worden omgegaan met bevriende relaties en familierelaties. Het antwoord daarop is om een opdracht niet zelf uit te voeren, maar die over te dragen aan collega's.

Ik heb bijvoorbeeld een buurman van mij en daar ben ik goed bevriend mee die heeft een hoge positie bij een bank. Als hij mij zou vragen voor een opdracht. Dan weet ik niet of ik dan zelf aan die opdracht zal meewerken. Dan zou ik wel andere mensen sturen. (Partner, Advisory).

\section{De vergelijking}

De vraag is gesteld of er formele regels bestaan voor informeel klantcontact binnen de organisatie waar de 
Tabel 3 Vraag of er formele regels zijn op het gebied van informeel klantcontact

\begin{tabular}{|l|c|c|}
\hline Zijn er formele regels op het gebied van informeel klantcontact? & Accountants (9) & Adviseurs (11) \\
\hline Ja zeker, strengere integriteitregels zijn van toepassing & 4 & 4 \\
\hline Misschien zijn de codes of conduct van toepassing & 3 & 1 \\
\hline Nee - niet dat ik weet & 1 & 1 \\
\hline Blanco/vraag niet beantwoord & 1 & 5 \\
\hline
\end{tabular}

accountant of adviseur werkzaam is. In tabel 3 staat het overzicht. Deze vraag is expliciet gesteld aan de twintig eerder geselecteerde respondenten (zie methodesectie). De antwoorden laten zien dat de antwoorden van accountants en adviseurs elkaar niet veel ontlopen; zowel accountants als adviseurs verwijzen naar integriteitsregels en codes of conducts, al twijfelt een deel of ze van toepassing zijn.

Op de vraag of de onafhankelijkheidspositie van de accountant of de adviseur wordt aangetast door het ontplooien en onderhouden van informele klantcontacten, bleek dat de meeste respondenten van mening waren dat informele contacten de onafhankelijkheid niet in de weg hoeven te staan. Sommigen stelden zelfs dat informeel contact de onafhankelijkheid juist kan versterken. Een betere band zorgt ervoor dat accountants en adviseurs eerlijker, kritischer en directer kunnen zijn. In tabel 4 is het overzicht van de reacties op deze vraag zichtbaar gemaakt. De vraag die werd gesteld is: in hoeverre tasten informele klantcontacten de onafhankelijkheidspositie aan van de accountant of adviseur?

Het verschil in businessmodel tussen accountants en adviseurs wordt geregeld genoemd als verklaring voor mogelijke verschillen: adviseurs hebben vaker korte termijncontracten (variërend van een paar maanden tot een jaar) waardoor zij veel actiever bezig zijn met het binnenhalen van nieuwe opdrachten, terwijl accountants vaker langdurige contracten hebben (meestal een paar jaar, zelfs soms tien - vijftien jaar).

In tabel 5 zijn de belangrijkste overeenkomsten en verschillen tussen accountants en adviseurs weergegeven. In het geval van vriendschappelijke en familierelaties is de regel bij beide professies om de klant door te geven aan een collega. De tabel laat goed zien dat er grote overeenkomsten bestaan. We zullen in het onderdeel analyse echter ook uitgebreid stilstaan bij het verschil in perspectief tussen accountants en adviseurs en de uitwerking daarvan op informele klantcontacten.

\section{ANALYSE}

\subsection{Informele klantrelatie: afstandelijkheid, betrokkenheid en spanningen}

Dit onderzoek laat een grote variëteit aan activiteiten zien die door adviseurs en accountants worden ontplooid om informele contacten te onderhouden. Naast de bekende voorbeelden van informele ruimtes zoals restaurants en cafés, worden er veel meer ruimtes betreden - en meer activiteiten ontplooid - dan er tot dusver beschreven zijn in de literatuur (Sturdy et al., 2006). De activiteiten bevinden zich op het raakvlaak van kunst, cultuur, sport en eten. Inhoudelijke events zoals conferenties, seminars en round tables worden voornamelijk georganiseerd met het doel nieuwe klanten te werven. De events met een sterker informeel karakter zijn daarnaast ook bedoeld om de bestaande relaties te verstevigen. In lijn met de literatuur (Czerniawska, 2007; Maister, 2005) behoort de accountant/adviseur zich aan te passen aan de wensen van de klant. Deze aanpassing geldt echter slechts tot een bepaald hoogte: de meest geslaagde informele activiteiten bestaan uit activiteiten waarbij beide partijen het naar hun zin hebben. Uit ons onderzoek blijkt dat vooral de adviseur in staat is om flexibel te balanceren tussen de verschillende, en soms tegenstrijdige, rollen die hij moet spelen. Bij de adviseur is bovendien het aanpassingsvermogen veel groter dan bij de accountant. De accountant switcht minder vaak tussen de verschillende rollen, zoals

\section{Tabel 4 Informele klantcontacten ten opzichte van de professionele onafhankelijkheidspositie}

\begin{tabular}{|l|c|c|}
\hline $\begin{array}{l}\text { In hoeverre tasten informele klantcontacten de professionele onafhankelfjkheid van } \\
\text { accountant of adviseur aan? }\end{array}$ & Accountants (9) & Adviseurs (11) \\
\hline Ja, het tast het aan & 0 & 1 \\
\hline Dat is mogelijk & 1 & 3 \\
\hline Het tast het niet aan & 5 & 5 \\
\hline Juist niet, informeel klantcontact maakt het juist gemakkelijker om onafhankelijk advies te geven & 3 & 1 \\
\hline Blanco/vraag niet beantwoord & 0 & 1 \\
\hline
\end{tabular}


Tabel 5 Belangrijkste overeenkomsten en verschillen tussen accountants en adviseurs

\begin{tabular}{|l|l|l|}
\hline $\begin{array}{l}\text { Aspecten die betrekkingen hebben op } \\
\text { informele klantrelaties }\end{array}$ & \multicolumn{1}{|c|}{ Accountants } & \multicolumn{1}{c|}{ Adviseurs } \\
\hline De zakelijke betekenis van informele klantcontacten & $\begin{array}{l}\text { Informele contacten vergemakkelijken soepele } \\
\text { kennisoverdracht en zorgen voor een vertrouwensband, } \\
\text { die nodig is voor een langetermijn-relatie }\end{array}$ & $\begin{array}{l}\text { Korte contracten, minder wederkerende } \\
\text { relaties: waardoor meer prikkels voor } \\
\text { relatiebeheer en werving (vervolgopdrachten) }\end{array}$ \\
\hline Motief voor informele klantcontacten & Nadruk op werkrelatie & Nadruk op vervolgopdrachten \\
\hline De rol van interne gedragscodes & Houvast voor twijfelsituaties & $\begin{array}{l}\text { Bevestiging van de professionele rol die de } \\
\text { dienstverlener dient te hebben }\end{array}$ \\
\hline $\begin{array}{l}\text { Houding wanneer relatie te vriendschappelijk dreigt } \\
\text { te worden of wanneer een vriend of familie klant wil } \\
\text { worden. }\end{array}$ & Klant overdragen aan collega & Klant overdragen aan collega \\
\hline Houding wanneer de relatie niet van de grond komt. & Klant overdragen aan collega & Klant overdragen aan collega \\
\hline
\end{tabular}

in lijn met het werk van Whittle (2006). De accountant mag absoluut niet bevriend raken met een klant en kan zichzelf ook niet vinden in de omschrijving van cocreator. Zij of hij zou zichzelf eerder beschrijven als een wetenschapper die met objectieve blik onderzoek verricht en verslag doet van wat zij/hij waarneemt. Mocht een zakelijke relatie zich ontwikkelen tot een vriendschappelijke relatie, dan wordt de relatie per direct overgedragen aan een collega omdat de accountant anders geacht wordt zijn werk niet meer goed te kunnen doen. Deze no-go areas hebben dus zeker een impact op de manier waarop de accountant-klant relatie er uitziet en hoe deze zich ontwikkelt.

Er zijn duidelijke verschillen tussen informele omgangsvormen en informele settings. Dit is een interessante toevoeging, omdat het verklaart waarom adviseurs en accountants andere strategieën ontplooien. Adviseurs hebben minder toegang tot de klant en gaan dientengevolge meer op zoek naar informele ruimtes. Accountants daarentegen worden daarin juist beperkt door de onafhankelijkheidregels. Een ander interessant verschil is dat bij de accountant-klantrelatie de adviseur meestal de vragende partij is die het voorstel voor een afspraak doet, terwijl in het geval van de accountant-klantrelatie het verzoek van beide kanten komt.

\subsection{Institutionele inbedding: de regels}

In tegenstelling tot wat men zou verwachten blijkt dat de aard van de activiteiten die buiten kantoor plaatsvinden elkaar niet zo veel ontlopen binnen de beide professies. De frequentie bij accountants is daarentegen kleiner dan bij de adviseurs. We kunnen constateren dat de accountants en adviseurs die werkzaam zijn binnen de Big 4 steeds meer op elkaar zijn gaan lijken door een toename van institutionele en commerciële druk (het grote belang van vervolgopdrachten). Beide groepen beamen dat zij door informele klantrelaties en een daarmee samenhangende, grotere betrokkenheid beter in staat zijn de klant te adviseren. Zij zijn zich echter tegelijkertijd zeker bewust van de gedragscodes en erkennen allen de noodzaak van een zekere professionele afstandelijkheid. De verschillen zijn vooral te vinden in de motieven voor informele klantcontacten en in de wijze waarop gedragsregels worden ervaren. Het is zeker niet zo dat de gedragsregels informele klantcontacten in de weg staan.

Door middel van informele klantrelaties menen accountants beter in staat te zijn hun klant te adviseren. De bestaande regels hebben naar hun mening geen invloed op de hoeveelheid informele contacten die zij onderhouden en brengen hun onafhankelijkheid niet in gevaar. Dit is in lijn met eerder onderzoek door Gendron et al. (2006), die eveneens aantonen aan dat grote betrokkenheid bij de klant geen obstakel hoeft te vormen voor de onafhankelijkheidspositie. Betrokkenheid en onafhankelijkheid kunnen elkaar juist versterken. Wél is de vorm van het informele contact belangrijk. De relatie mag niet té los, té open of té vriendschappelijk worden. Vriendschap en familierelaties tasten de onafhankelijkheid wel aan, zoals we hebben kunnen zien.

\subsection{De slotvergelijking}

Als we nauwkeurig kijken, zien we - ondanks de hierboven gesignaleerde overeenkomsten - toch wezenlijke verschillen in de manier waarop beide professionele partijen praten over hun motieven om informele banden aan te gaan en over de invloed van formele regels. Zoals de tabel hieronder laat zien is er wat dat betreft een duidelijk onderscheid waar te nemen tussen accountants en adviseurs. Het duidelijkst is te zien dat de accountants afstand proberen te bewaren (de klant mag niet te dichtbij komen); terwijl de adviseurs juist zo dichtbij mogelijk proberen te komen. De adviseurs hebben het vaak over bijna-vriendschap, gezelligheid, passies en 'dat een goede relatie gewoon leuk is'. De 
adviseurs gaan ook wat soepeler om met de regels, hoewel zij zich zeer bewust zijn van de bestaande regels omtrent het geven en ontvangen van geschenken. Mochten zij twijfelen of informeel gedrag past binnen de normen van het bedrijf, dan consulteren zij de regels of vragen een collega om advies. De regels worden door de adviseurs niet ervaren als beklemmend of beperkend, aangezien zij voldoende ruimte laten om informele activiteiten te ontplooien of op een andere manier een vertrouwensband te ontwikkelen met de klant. De accountants daarentegen zien de onafhankelijkheidsregels als een cruciaal en leidend onderdeel van de professie, als fundamentele bouwstenen: ze zijn helder en bieden houvast.

Het verschil tussen de twee professies is uiteindelijk terug te brengen tot het verschil in institutionele logica (Thornton en Ocasio, 1999, Rao et al., 2003): de logica van de markt van de adviseur (klantenbinding, veiligstelling van vervolgopdrachten) versus de logica van de expertise en professie van de accountant (duidelijke grenzen en afstand bewaren tot de klant). Bij de accountant hebben de regels een grotere invloed op de vormgeving van informele klantcontacten dan bij de adviseur. De regels zijn sturend voor de manier waarop informeel contact wordt vormgegeven. Voor de adviseur lijkt het andersom, de contacten zijn bepalend en sturend, en de adviseur kan prima opereren binnen de regels (zie tabel 6).

\section{Conclusie, suggesties voor vervolgonderzoek en aanbevelingen}

\subsection{Conclusie}

In onze exploratieve studie naar informeel klantcontact bij accountants en adviseurs komen de resultaten merendeel overeen met eerdere studies waarin het belang van klantbetrokkenheid, informele settings en codes of conduct worden beschreven. Nieuw aan deze studie is dat deze voor het eerst een specifieke vergelijking biedt tussen het informele klant- contact van accountants en adviseurs die werkzaam zijn binnen de Big 4-organisaties. Beide soorten professionals beamen dat informeel klantcontact een cruciaal onderdeel vormt van hun dagelijkse werkzaamheden. Ze stellen zelfs dat zonder informeel contact het werk niet kan worden uitgevoerd. Hoewel uit dit onderzoek blijkt dat de locaties waar het informele klantcontact van de accountants en adviseurs plaatsvindt min of meer hetzelfde zijn, maar de doelstelling en het belang van institutionele regels wezenlijk anders. Dit kunnen we verklaren aan de hand van de verschillen in business model en institutionele logica tussen beide beroepsgroepen (het verschil in de gemiddelde duur van de klantrelatie en de professionele inbedding).

\subsection{Suggesties voor vervolgonderzoek}

Ons onderzoek roept vragen op over 'vorm' en 'inhoud'. Is het gevolg van de nadruk op het klantcontact dat de vorm van de relatie belangrijker is dan de vakkennis? Of gaan beide hand in hand? Zoals de eerder aangehaalde adviseurpartner het verwoordde: 'Met mooie verhalen red je het niet en ook niet met alleen maar inhoud.' Vakkennis is een eerste vereiste volgens deze respondent. De menselijke interactie komt daar bovenop. Anderen zien informeel contact meer als een middel om vakkennis te vergaren. Naar hun mening is het niet mogelijk om zonder informeel contact echt inhoudelijk te worden. Wij herhalen in deze context graag de eerder aangehaalde accountancy-partner die stelt dat in de loop der tijd het gesprek een andere wending krijgt: het gesprek gaat dieper en gaat uiteindelijk over de strategie van de klantonderneming.

Het is interessant om hier een discussie in De Accountant van april 2011 aan te halen, waarin KPMG bestuursvoorzitter Ben van der Veer stelt dat de accountant te voorzichtig is. Accountants zouden: 'meer moeten communiceren met elkaar als met hun opdrachtgevers en maatschappelijke partners: publiek, politiek, toezichthouders' (Dekker, 2011, p. 22). Hij signaleert te veel voorzichtigheid bij accountants

Tabel 6 De verschillende repertoires van accountants en adviseurs

\begin{tabular}{|l|l|l|}
\hline Repertoires & \multicolumn{1}{|c|}{ Motieven } & \multicolumn{1}{|c|}{ De regels } \\
\hline Accountants & $\begin{array}{l}\text { - Pragmatisch: informeel contact is noodzakelijk voor } \\
\text { informatie-uitwisseling } \\
\text { - Inhoudelijk gemotiveerd }\end{array}$ & $\begin{array}{l}\text { - Zeer belangrijk: geeft houvast, bouwstenen } \\
\text { van de professie } \\
\text { - Niet te dichtbij komen! (emotie: 'als de } \\
\text { sodemieter wegwezen als de klant te } \\
\text { dichtbij komt') }\end{array}$ \\
\hline Consultants & $\begin{array}{l}\text { - Intimiteit, dichtbij staan, sterke band ontwikkelen } \\
\text { ('Het is leuk') } \\
\text { - Vertrouwen ontwikkelen } \\
\text { - Passie en emotie }\end{array}$ & $\begin{array}{l}\text { - Pragmatisch: goed op te zoeken mocht het } \\
\text { nodig zijn } \\
\text { - Niet heel belangrijk (niet paraat) } \\
\text { - Genoeg ruimte tussen de regels } \\
\text { - Gezond verstand gebruiken } \\
\text { - Collega's raadplegen in geval van twijfel }\end{array}$ \\
\hline
\end{tabular}


en een voorkeur voor formele procedures. Volgens Van der Veer is er voldoende ruimte voor de accountant om zijn/ haar mening te geven op basis van zijn/haar persoonlijke, professionele ervaringen. Dit onderwerp - de eigen mening van de accountant (naast de formele audit) versus de verdere juridisering van de accountancy professie - zou een interessant onderwerp vormen voor vervolgonderzoek. In het verlengde hiervan is het ook interessant om te kijken naar de invloed van de accountancy professie op de advisory werkzaamheden van de adviseurs bij de Big 4. Hebben adviseurs die werkzaam zijn bij de Big 4-organisaties meer te maken met 'juridisering' van het werk (belang van codes, engagement letters, contracten) dan strategie adviseurs die niet werkzaam zijn bij Big 4-organisaties?

Vervolgonderzoek zou ook kunnen ingaan op het verschil tussen de wijze waarop vrouwelijke senior managers en partners uit de accountancy en advisory organisaties informeel omgaan met hun klanten (zie ook Anderson-Gough et al., 2005), in vergelijking met hun mannelijke collega's. Ondernemen zij bijvoorbeeld andersoortige activiteiten?

Ons onderzoek roept ook de vraag op in hoeverre onze bevindingen en analyse van toepassing zijn op kleinere advies- of accountancyorganisaties. We vermoeden dat de controle- en monitoringsystemen om eventuele misstappen in informele klantrelaties te signaleren minder ontwikkeld zijn dan bij de Big 4-organisaties. Daarentegen verwachten we dat er in een kleinere organisatie meer sociale controle plaatsvindt met een overeenkomstig preventief effect. Verder onderzoek hierna zou wellicht een interessante vergelijking opleveren.

We hebben geen onderzoek gedaan naar de waarde die door adviseurs en accountants wordt toegekend aan het lidmaatschap van verenigingen en sociëteiten. Evenmin hebben we onderzoek gedaan naar informele contacten die plaatsvinden tijdens trouwerijen en begrafenissen. Voor vervolgonderzoek zou, in lijn met het werk van Heemskerk (2007) naar de Nederlandse elite, het zeker interessant zijn om deze settings nader te bestuderen.

Tenslotte zou een onderzoek naar trainingsmogelijkheden een interessant onderwerp voor vervolgonderzoek zijn. Op welke wijze zouden deze soft skills-vaardigheden het beste kunnen worden ontwikkeld? Zou dit door middel van aparte trainingen moeten plaatsvinden (als toevoeging aan de bestaande sales-trainingen) of via training on the job? En wat zijn de uitdagingen bij het zoeken naar een juiste balans met betrekking tot onafhankelijkheid, het vervullen van de expertrol en het fenomeen vriendschap en familie? Dit brengt ons tot onze aanbevelingen.

\subsection{Aanbevelingen}

Voor aanbevelingen op overheidsniveau is het met name van belang dat de professionals vasthouden aan de door de overheid opgelegde, dan wel zelfopgelegde regels (bijvoorbeeld door de professies of de organisaties). Om er voor te zorgen dat de professionals zich aan de regels houden is het belangrijk dat de monitoring systemen goed functioneren. Transparantie en aansprakelijkheid zijn belangrijk mechanismen die hiervoor kunnen zorgdragen.

We willen graag eindigen met aanbevelingen voor de accountants. Hoewel het belang van informeel contact (al dan niet in een informele setting) vaak werd bevestigd door de respondenten, blijkt zulk contact vaak niet eenvoudig. Zowel de adviseur als de accountant hebben te maken met vragen over de grenzen tussen werktijd en eigen tijd, tussen zakelijk en privé. De adviseur blijkt soepel in de verschillende situaties en rollen te kunnen opereren. Het onderzoek laat zien dat accountants, in vergelijking met adviseurs, laat beginnen met het trainen van hun medewerkers op het onderhouden van klantcontacten. Hierdoor kunnen ze deze vaardigheid pas laat in hun carrière ontplooien. Hoewel wij begrijpen dat binnen het accountancyvak sterk de nadruk ligt op het verkrijgen van vakinhoudelijke kennis, zou het toch goed zijn om meer nadruk te leggen op het ontwikkelen van soft skills binnen de professie.

Dr. Y. Taminiau is universitair docent Strategie aan de VU (Ph-D RSM). Haar onderzoek richt zich op het belang van informeel klantcontact binnen de accountancy en advisory professies en de impact van institutionele druk op beide beroepsgroepen.

Dr. L. Berghman is universitair docent Strategie aan de VU

(Ph-D RSM). Haar onderzoek richt zich op Customer

Relationship Management en intra- en inter-organisatorische precondities voor niet-technologische innovaties. Berghman heeft ervaring als strategieconsultant. 
1. De auteurs willen graag de respondenten heel hartelijk danken voor hun medewerking. We willen ook graag Marc Bout en Leonie de Groot zeer hartelijk danken voor hun betrokkenheid bij de uitvoering van het empirisch onderdeel van de studie. Tot slot, willen we graag professor Andrew Sturdy, professor George Molenkamp, Arnoud Kuijpers, Arjan de Draaijer en Reinier Labadie danken voor hun enthousiasme en steun gedurende het gehele project.

2 KPMG, Ernst \& Young, Deloitte en PriceWaterhouseCoopers.
3 Adviseur en consultant worden als synoniemen gebruikt, hetzelfde geldt voor advisory en consultancy. In dit artikel wordt in het algemeen de term adviseur gebruikt.

4 Deze gedragscode komt in Nederland vanuit het Koninklijk Nederlands Instituut van Register Accountants (NIVRA, 2009); vanaf 2011 Nederlandse Beroepsorganisatie van Accountants (NBA). Twee centrale artikelen uit de NIVRA gedragscode met betrekking tot de onafhankelijkheid van een accountant (2009): Artikel A-120.1 De registeraccountant laat niet toe dat zijn professionele of zakelijk oordeel wordt aangetast door een vooroordeel, belangentegenstelling of ongepaste beïnvloeding door een derde. Artikel A-120.2 De registeraccountant vermijdt iedere situatie die zijn professionele oordeelsvorming op een ongepaste wijze beïnvloedt.

5 Het is niet zo dat de respondenten konden kiezen uit deze vijf categorieën, maar zij ontstonden door de analyse van het antwoordmateriaal.

\section{Literatuur}

- Alvesson, M. en A. Johansson, (2002), Professionalism and politics in management consultancy work, in: Clark, T. and Fincham, R. (eds.), Critical consulting, Blackwell Oxford, pp. 228-246.

- Anderson-Gough, F., C. Grey en K. Robson (2005), Helping them to forget..: the organizational embedding of gender relations in public audit firms, Accounting, Organizations and Society, vol. 30, pp. 469-490.

- Appelbaum, S.H. en A.J. Steed (2005), The critical success factors in the client-consultant relationship, Journal of Management Development, vol. 24, no. 1, pp. 68-93. - Bacharach, S.B. (1989), Organizational theories: Some criteria for evaluation, Academy of Management Review, vol. 14, no. 4, pp. 496-515.

- Berglund, J. en A. Werr (2000), The invincible character of management consulting rhetoric: How one blends incommensurates while keeping them apart, Organization, vol. 7, no. 4, pp. 633-655.

- Bollom, W. J. (2004), Ethics and self-regulation for CPAs, Journal of Business Ethics, vol. 7, no. 1-2, pp. 55-61.

- Burchell, S., C, Clubb, A. Hopwood, J. Hughes en J. Nahapiet (1980), The roles of accounting in organizations and society, Accounting, Organizations and Society, vol. 5, no. 1, pp. 5-27. - Clark, T. en G. Salaman, (1998), Creating the 'right' impression: Towards a dramaturgy of management consultancy, Services Industry Journal, vol. 18, no. 1, pp. 18-38.
Clark, T. (1995), Managing consultants: Consultancy as the management of impressions. Buckingham: Open University Press.

- Czarniawska, B. en C. Mazza (2003), Consulting as a liminal space, Human Relations, vol. 56, no. 3, pp. 267-290.

- Czerniawska, F. (2007), The trusted firm: How consulting firms build successful client relationships. West Sussex: Wiley.

- Dekker, G. (2011), Ben van der Veer, Ex-KPMG, nu multi-commisaris. 'Het moet assertiever, steviger en prikkelender', De Accountant, 2011, nr. 4 (april), pp. 22-26.

- Diller J. (1999), A social conscience in the global marketplace? Labour dimensions of codes of conduct, social labelling and investor initiatives, International Labour Review, vol. 138, no. 2, pp. 99-129.

- Gendron, Y., Suddaby, R. en H. Lam (2006), An examination of the ethical commitment of professional accountants to auditor independence, Journal of Business Ethics, vol. 64, pp. 169-193.

—Glückler, J. en T. Armbrüster (2003), Bridging uncertainty in management consulting: The mechanisms of trust and networked reputation, Organization Studies, vol. 24, no. 2, pp. 269-297. - Hayes, R., R. Dassen, A. Schilder en P. Wallage (2005), Principles of Auditing - An introduction to international standards on auditing, Second Edition. Prentice Hall-Harlow. - Heemskerk, E.M. (2007), Decline of the corporate community, Network of the Dutch business elite, Amsterdam: Amsterdam University Press.
Kanter, R. M. (1977), Men and women of the corporation, New York: Basic Books.

- Heusinkveld, S. en J. Benders (2005),

Contested commodification: Consultancies and their struggle with new concept development, Human Relations, vol. 58, no. 3, pp. 283-310. - Kaptein M. en P. Wallage, Assurance over gedrag en de rol van soft controls: een lonkend perspectief, Maandblad voor Accountancy en Bedrijfseconomie, vol. 84, no. 12, pp. 623-632. - Kitay, J. en C. Wright (2004), Take the money and run? Organisational boundaries and consultants roles, The Service Industries Journal, vol. 24, no. 3, pp. 1-18.

- Kubr, M. (2002), Management consulting: A guide to the profession (4th ed.). Geneva: International Labour Organization.

- Maister, D. H. (2005), The Consultant's Role. www.davidmaister.com.

- Maxwell, J.A. (1998), Designing a qualitative study, in: L. Bickman en D.J. Rog (Eds.), Handbook of Applied Social Research Methods, Thousand Oaks, CA: Sage Publications, pp. $69-100$.

- Rao, H., P. Monin en R. Durand (2003), Institutional Change in Toque Ville: Nouvelle Cuisine as an Identity Movement in French Gastronomy, American Journal of Sociology, vol. 108, no. 4, pp. 795-843.

- Strauss, A. (1987), Qualitative analysis for social scientists. New York: Cambridge University Press.

- Strikwerda, J. (2000), De organisatieadviseur, professionele of zakelijke dienstverlening? 
Maandblad voor Accountancy en

Bedrijfseconomie, vol. 74, no. 12, pp. 553-559.

- Sturdy, A., M. Schwarz en A. Spicer (2006) Guess who's coming to dinner? Structures and uses of liminality in strategic management consultancy, Human relations, vol. 59, no. 7, pp. 929-960.

- Taminiau, Y., W. Smit en A. de Lange (2009), Innovation in management consulting firms through informal knowledge sharing, Journal of Knowledge Management, vol. 13, no. 1 , pp. 42-55.
- Thornton P. en W. Ocasio (1999), Institutional logics and the historical contingency of power in organizations: Executive succession in the higher education publishing industry, 1958-1990, American Journal of Sociology, vol. 105, no. 3, pp. 801-843.

- Vergoossen R. en P. Wallage (2004), Toezicht op het accountantsberoep, Ontwikkelingen in de Verenigde Staten, het Verenigd Koninkrijk, Nederland en Duitsland, Maandblad voor Accountancy en Bedrijfseconomie, vol. 78 , nr. 12, pp. 542-553
- Wallage, P. (2008), De toekomst van het accountantsberoep, verandering als enige constante, Maandblad voor Accountancy en Bedrijfseconomie, vol. 82, no. 3, pp. 74-76. -Werr, A. en A. Styhre (2002), Management consultants - friend or foe? Understanding the ambiguous client-consultant relationship, International Studies of Management \& Organization, vol. 32, no. 4, pp. 43-66.

- Whittle, A. (2006), The paradoxical repertoires of management consultancy, Journal of Organizational Change Management, vol. 19, no. 4, pp. 424-436. 